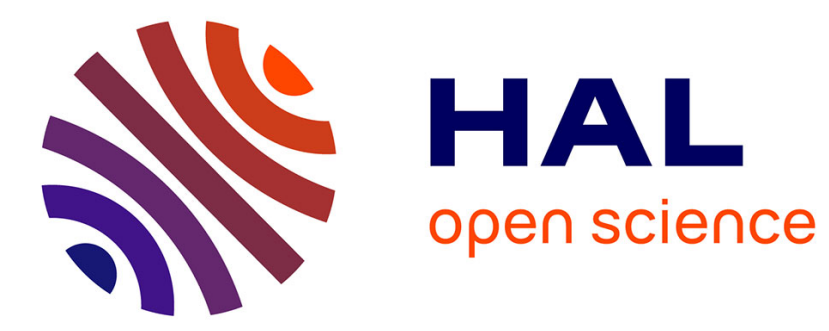

\title{
Implementation of Proteomics Biomarkers in Nephrology: From Animal Models to Human Application?
}

Julie Klein, Joost P. Schanstra

\section{- To cite this version:}

Julie Klein, Joost P. Schanstra. Implementation of Proteomics Biomarkers in Nephrology: From Animal Models to Human Application?. PROTEOMICS - Clinical Applications, 2019, 13 (2), pp.1800089. 10.1002/prca.201800089 . inserm-02481347

HAL Id: inserm-02481347 https://www.hal.inserm.fr/inserm-02481347

Submitted on 17 Feb 2020

HAL is a multi-disciplinary open access archive for the deposit and dissemination of scientific research documents, whether they are published or not. The documents may come from teaching and research institutions in France or abroad, or from public or private research centers.
L'archive ouverte pluridisciplinaire HAL, est destinée au dépôt et à la diffusion de documents scientifiques de niveau recherche, publiés ou non, émanant des établissements d'enseignement et de recherche français ou étrangers, des laboratoires publics ou privés. 


\title{
Implementation of proteomics biomarkers in nephrology:
}

\section{From animal models to human application?}

Julie Klein ${ }^{1,2}$ and Joost P Schanstra ${ }^{1,2}$

\author{
1 Institut National de la Santé et de la Recherche Médicale (INSERM), U1048, Institut of \\ Cardiovascular and Metabolic Disease, Toulouse, France. \\ ${ }^{2}$ Université Toulouse III Paul-Sabatier, Toulouse, France.
}

\begin{abstract}
Abbreviations: AKI, acute kidney injury; CKD, chronic kidney injury; uEGF, urinary EGF; ACR, urinary albumin to creatinine ratio; $\mathrm{Cr}$, urinary creatinine; I/R, ischemia reperfusion; MMF, Mycophenolate mofetil: MPA, mycophenolic acid; EMT, epithelial to mesenchymal transition; EPO, Erythropoietin; CHBP, conformationally constrained cyclized helix B peptide; RASi, renin angiotensin system inhibitors; CVD, cardiovascular disease; ZDF, Zucker diabetic fatty.
\end{abstract}

Keywords: biomarker, preclinical, translational research, urine.

Total number of words (including references as well as figure and table legends): 5542 


\section{Abstract}

Preclinical animal models are extensively used in nephrology. In this review we have assessed the utility of performing proteome analysis of kidney tissue or urine in such models and transfer of the results to human application. Analysis of the literature identified 68 relevant publications. Pathway analysis of the reported proteins clearly indicated links with known biological processes in both acute and chronic kidney disease providing validation of the observed changes in the preclinical models. Most studies in the models focused on the identification of early markers of kidney disease or prediction of its progression. However, none of the identified makers has made it to substantial validation in the clinic or at least in human samples. It therefore appears that, especially in renal disease where urine is often used as a source of biomarkers, the focus should be on human material based discovery studies. In contrast, we observed that proteome analysis of preclinical models was most useful in the context of drug evaluation, both in terms of assessing efficacy for translation to human disease and for mechanistic insight. 


\section{Introduction}

A plethora of animal models of kidney disease exist, ranging from models of acute kidney disease (AKI) to chronic kidney disease (CKD) models ${ }^{[1]}$. These models differ by their damaging mechanism (cell toxicity, immune mechanisms, surgical renal mass reduction, ischemia, diabetes, hypertension, ureter obstruction etc.), functional and histomorphological phenotype and disease evolution. These models have been used to dissect the roles of specific molecules/targets or biological processes and for preclinical drug testing. However these models have also been investigated with kidney or urine proteome analysis with the aim to discover novel biomarkers of kidney disease. Here we review to which extent such proteome-based analyses have been helpful in the identification of new proteinbased biomarkers in nephrology and their potential translation or use towards human application. With that aim we have searched the scientific literature using the Web of Science on 02/07/2018 with the following search parameters: [kidney OR nephro*] in the title AND [proteom* OR peptidom*] AND [animal OR mouse OR rat] in the topic. This lead to the identification of 321 citations of which 265 were identified as original articles by the Web of Science. In the next step we only retained publications that were cited at least 5 times to focus on studies with a potential impact. This lead to a list of 167 publications (Supplementary Table 1). Manual inspection of this list resulted in the exclusion of 99 publications due to the fact that these studies were either reviews, focused on other omics traits, used cells, were methodology focused, did not employ kidney disease animal models, or lacked proof of well-defined kidney lesions (Supplementary Table 1).

\section{i) Pathway analysis of proteome data of preclinical kidney disease models}

To determine the validity of the proteome data obtained in preclinical models of kidney disease, proteome data from the 68 remaining studies were combined and analyzed using pathway analysis to determine the relevance of the identified proteins in known kidney disease processes. We collected the proteins, separately for AKI and CKD, mentioned in the abstracts of the publications and their expression directions, considering that proteins mentioned in publication abstracts are 
representative of the studies (Table $\mathbf{1}$ and 2). Proteins with contradictory expression directions were removed. The proteins were analyzed using Ingenuity Pathway Analysis (supplementary Table $\mathbf{2}$ and 3 for AKI and CKD, respectively). Interestingly, the analyses confirm relevance of the selected proteins to existing knowledge on the biological processes involved in AKI and CKD, but with typical differences. For example, acute phase response signaling was the top canonical pathway identified in AKI, while actin cytoskeleton signaling was the major canonical pathway in CKD. The former fits perfectly with the acute character of AKI while actin cytoskeleton signaling can be traced back to the mostly glomerular changes observed in CKD. The major networks identified, also fit with the underlying knowledge of these main etiologies. The top disease network in CKD was attributed to cardiovascular disease (Figure 1A). In AKI, free radical scavenging was the top (dys)functional network (Figure 1B) confirming potential use of oxygen-free radical scavengers in the treatment of AKI ${ }^{[2]}$. Therefore, overall, the data extracted from these proteome-based studies in preclinical kidney disease models appear to have validity when comparing to the currently known diseaseinvolved biological mechanisms.

ii) Use of preclinical model kidney proteome analysis in biomarker discovery with initial validation in human kidney disease

Eleven studies focusing on identification of novel biomarkers for early detection of kidney diseases contained a (initial) validation in humans in the same report. Three of those were excluded due to the absence of follow-up studies 7-20 years after initial publication and absence of a role of these proteins in kidney disease. One study was excluded since no specific proteins were mentioned in the abstract and one study developed a method for improved translation of preclinical proteome-based data to the clinic and was moved to section IV of the manuscript.

Epidermal growth factor in CKD - The modification of epidermal growth factor (EGF) expression in almost any kidney disease model has focused attention on EGF signaling ${ }^{[3]}$. EGF signals through the epidermal growth factor receptor (EGFR) involved in multiple biological processes, 
including proliferation, metabolism, differentiation, and survival. Kidney-specific overexpression of a dominant negative EGFR in mice made those mice resistant to development of fibrosis in models of chronic kidney injury induced by ischaemia-reperfusion and renal ablation. In addition, silencing of EGFR expression in proximal tubules slowed down the development of fibrosis in an Ang II-infusion model. Small molecule inhibitors of EGF signaling such as erlotinib and gefitinib also delayed or reduced fibrosis in several CKD and AKI models ${ }^{[3]}$. The value of EGFR inhibitors for the treatment of cancer has been clearly established in clinical trials, however trials have not yet been initiated in kidney disease (https://clinicaltrials.gov/, search with key words [EGF OR epithelial growth factor] AND [kidney] in August 2018).

Betz et al. ${ }^{[4]}$ examined the urinary protein content of a novel rat model of hypertensive diabetic nephropathy, a CKD model resulting in a 500-fold increase in albuminuria and marked glomerulosclerosis and tubulointerstitial fibrosis. Using a combination of peptidome and ELISA analysis, the authors showed using this animal model that urinary EGF (UEGF) abundance was significantly reduced as early as 8 weeks after induction of hyperglycemia and hypertension. An important strength of the study by Betz et al. ${ }^{[4]}$ was to have tested, following the observation in the animal model, the predictive value of UEGF in a large type 2 diabetic human cohort. They observed that uEGF/urinary creatinine $(\mathrm{Cr})$ was weakly associated to baseline eGFR and the patients with lowest $\mathrm{UEGF} / \mathrm{Cr}$ values displayed a significant increased risk $(\mathrm{p}=0.003)$ of renal function decline during the 4-year follow-up. In contrast, the urinary albumin to creatinine ratio (ACR) was not a useful prognostic indicator. This study suggests that initiating a biomarker strategy from well-calibrated animal models can lead to valid observations in the human population. However, and unfortunately, uEGF/Cr did not show any improved predicted value when combined with established risk factors of diabetic nephropathy such as age, gender, eGFR, ACR, duration of diabetes, $\mathrm{HbA1c}$, systolic and diastolic blood pressure. Although the authors showed the potential of UEGF in the prediction of diabetic nephropathy, it is clearly not specific since reduced uEGF is also observed in AKI, IgA nephropathy, in children with chronic kidney failure and in congenital ureteropelvic junction 
obstruction ${ }^{[3,5]}$. Moreover, a recent 2018 study adding uEGF to a panel of circulating markers (TNFR1, KIM-1, and FGF23), of urinary markers (albumin, KIM-1, NGAL, MCP-1, EGF, all normalized to urinary creatinine) and the ratio of EGF to MCP-1, showed that this multimarker prognostic test had low value in identifying patients with early renal decline in type 2 diabetic patients with normoalbuminuria, and only moderate value in albuminuric patients. Therefore, there is still a great need to find new informative markers to develop a better prognostic test to identify early renal decline in patients with type 2 diabetic nephropathy and normal renal function ${ }^{[6]}$.

Regucalcin in CKD - Zubiri et al. performed a differential analysis of the renal tissue proteome in a rat model of early type I diabetic nephropathy ${ }^{[7]}$. Regucalcin (senescence marker protein-30 [SMP30]) that showed a 4-5-fold decrease in expression in rats with diabetic nephropathy was selected for further validation. This decreased expression was validated by Western blot, immunohistochemistry, and selected reaction monitoring using urinary exosomes in both rat and humans $(n=7)$. This recent study (2015) has not yet been followed-up by validation in additional studies involved human CKD subjects. However, there is supporting literature of a potential role of regucalcin in renal pathophysiology. Regucalcin has been found to be modified in hypertensive kidney disease, under nephrotoxicity conditions (Cisplatin, Ochratoxin A) and in interstitial renal disease induced by aristolochic acid. Regucalcin is a multifunctional protein shown to be involved in cellular $\mathrm{Ca}^{2+}$ homeostasis in proximal tubule cells and in some various fundamental processes including mineral transport, transcription factors, cell proliferation and apoptosis, all potentially involved in kidney disease ${ }^{[8]}$.

Fetuin-A in AKI - Two studies using animal models of AKI identified Fetuin-A as a potential biomarker of AKI ${ }^{[9,10]}$, although only one study validated modified urinary Fetuin-A expression in humans. Both studies employed one nephrotoxicity model (cisplatin-induced AKI) and one ischemia reperfusion (I/R) AKI model. In both models urinary Fetuin-A abundance was significantly increased in response to AKI. In the study of Zhang et al. increased urinary Fetuin-A abundance paralleled serum creatinine increase ${ }^{[10]}$ (i.e. renal function impairment), while in the study of Zhou et al. 
increased urinary Fetuin-A abundance preceded increased serum creatinine ${ }^{[9]}$. This difference might be due to the fact that Zhou et al. isolated urinary exosomes while Zhang et al. analyzed protein expression in total urine. It appears that Fetuin-A is mostly excreted in exosomes ${ }^{[9]}$ which are cellderived vesicles that are present in many eukaryotic fluids. Zhou et al. also studied the transferability of the observations by analyzing urinary exosomal abundance of Fetuin-A in a small number of healthy volunteers and ICU patients with and without AKI. They confirmed the increased abundance of Fetuin-A in subjects with AKI. However, no information on the biomarker potential of Fetuin-A to predict the development of AKI could be obtained from these experiments since patients were sampled while displaying already full blown AKI ${ }^{[9]}$. Furthermore, since initial publication in 2006, there have been no follow-up studies on urinary Fetuin-A for the development of human AKI which seems to compromise the value for Fetuin-A as a potential predictive biomarker in this clinical context. In addition, as for EGF, urinary Fetuin-A does not seem to be specific for AKI since it is apparently also associated with autosomal dominant polycystic kidney disease progression ${ }^{[11]}$. Although this would compromise the use of Fetuin-A as a predictive biomarker, it suggests a potential wider involvement in renal disease. Fetuin-A is synthesized in liver and secreted into the blood stream, where it is a negative acute-phase response protein and plays its anti-inflammatory role via suppressing release of tumor necrosis factor-alpha induced by lipopolysaccharide in vitro and vivo ${ }^{[12]}$. Fetuin-A is also a systemically acting inhibitor of ectopic calcification ${ }^{[13]}$, and decreased serum Fetuin-A concentration is associated with a higher mortality rate in dialysis patients and can predict mortality of chronic kidney diseases ${ }^{[14]}$. However, the role or function, if any, in AKI remains unknown.

Nestin in AKI - Zhang et al. used urinary proteome analysis to identify biomarkers of AKI in a cisplatin nephrotoxicity and renal I/R model ${ }^{[10]}$. Among other proteins, including Fetuin-A (see above), they identified nestin as a potential biomarker of AKI in both models. Nestin was validated in urine of humans with cardiac surgery-induced AKI $(n=10)$ compared to cardiac surgery patients not developing AKI $(n=30)$. Interestingly, urinary nestin abundance (nestin/creatinine) peaked 6 hours 
after surgery and before the rise in serum creatinine in the patients developing AKI. No additional validation of nestin as a biomarker in human AKI was performed since this study. Nestin is a cytoskeleton-associated class VI intermediate filament protein that was found to be highly expressed in podocytes and closely associated with podocyte function by maintaining the structural integrity of the podocytes ${ }^{[15]}$. In glomerular human disease increased nestin expression was observed in crescentic glomerulonephritis ${ }^{[16]}$ and appeared to be a potential new early morphological predictor of kidney dysfunction in childhood onset of FSGS ${ }^{[17]}$. In contrast, the role of increased tubular nestin expression in AKI is not clear. However, another study also identified increased tubular nestin expression in IgA nephropathy. In those patients increased nestin expression was found in the tubulointerstitium, probably peritubular endothelial cells and myofibroblasts, although its functional role was not studied ${ }^{[18]}$. Therefore the role of nestin in AKI both as a biomarker and as pathophysiological regulator remain elusive.

Chitinase 3-like protein 1 in AKI - Maddens et al. studied the urinary proteome of a mouse model of sepsis-induced AKI and validated potential candidates in urine from human sepsis-induced AKI. Urinary neutrophil gelatinase-associated lipocalin (NGAL), thioredoxin, gelsolin, chitinase 3-like protein 1 (CHI3L1) and $-3(\mathrm{CHI}$ L3) and acidic mammalian chitinase were the most distinctive candidate biomarkers of septic AKI in mice. However of the tested CHI3L1, NGAL and acidic mammalian chitinase, only CHI3L1 was found to display modified (increased) excretion in urine from septic patients with AKI compared to septic patients without AKI ${ }^{[19]}$. This observation sparked the interest of the authors to evaluate the predictive value of urinary CHI3L1 in predicting AKI or its severity in subsequent clinical studies. In a single center study recruiting 181 severely ill adult ICU patients, urinary CHI3L1 predicted the development of AKI stage $\geq 2$ (Kidney disease Improving global outcome (KDIGO) classification) with a reasonably well area under the curve (AUC) of 0.792 similar to urinary NGAL measured in the same study. Furthermore, increased urinary CHI3L1 abundance was associated to increased AKI severity after the event ${ }^{[20]}$. In a subsequent study, the group studied the association of urinary CHI3L1 to the development of AKI after cardiac surgery involving 211 patients. 
However, in this study urinary CHI3L1 was not predictive of AKI ${ }^{[21]}$. The biological roles of CHI3L1 have been for a long time particularly enigmatic, but data has shown that intrarenal macrophage CHI3L1 plays a key role in promoting tubular cell survival after renal I/R injury in mice via PI3K- and IL13 receptor $\alpha 2$-dependent signaling ${ }^{[22]}$. CHI3L1 can also bind to and activate a second receptor chemokine receptor homologous molecule expressed on Th2 lymphocytes (CRTH2; also called prostaglandin D2 receptor 2 [PTGDR2]), that induces profibrotic signaling in the setting of lung injury ${ }^{[23]}$. A recent study suggested that CHI3L1 and its downstream key-signaling pathways could be key in the transition from AKI to CKD. A model was proposed where tubular cells and/or endothelial cells that cannot undergo normal repair after I/R injury maintain low-level CHI3L1 expression that, in turn, signals to promote macrophage survival and profibrotic gene expression as well as myofibroblastdependent matrix gene expression. Thus, therapies directed against sustained CHI3L1 expression and/or its downstream profibrotic signaling would be logical targets to be considered in prevention of progressive fibrosis after ischemic AKI ${ }^{[24]}$.

iii) Use of preclinical model kidney proteome analysis in drug testing

Mycophenolate mofetil (MMF) - MMF as a prodrug of mycophenolic acid (MPA) is one of the most frequently used immunosuppressive drugs for the prophylaxis of allograft rejection after renal, cardiac, or liver transplant. MPA is a potent, selective, noncompetitive, and reversible inhibitor of inosine-5'-monophosphate dehydrogenase (IMPDH). Depleting guanosine and deoxyguanosine nucleotides inhibit the proliferation of $\mathrm{T}$ and $\mathrm{B}$ lymphocytes and, hence, immunoglobin production conferring the immunosuppressive effect of $\mathrm{MMF}^{[25]}$. However antifibrotic properties have also been attributed to MPA, although the detailed mechanism was not known. With aim to unravel the antifibrotic properties of MPA, Petrova et al. studied the effect of MMF treatment using differential kidney proteome profiling of COL4A3-deficient mice as a model of progressive renal disease ${ }^{[26]}$. Tubulointerstitial fibrosis in COL4A3-deficient mice was inhibited by MMF treatment. Although the role and contribution of epithelial to mesenchymal transition (EMT) in the development of renal 
tubulointerstitial fibrosis is still debated ${ }^{[27]}$, proteome analysis identified differentially expressed proteins that had a potential association to EMT, i.e. 2 upregulated (actin cytoplasmic 2 [ACTG] and ubiquitin carboxyl-terminal hydrolase 5 [UBP5]) and 5 downregulated proteins (carbonic anhydrase 1 [CAH1], proteasome subunit beta type 6 [PSB6], tumor protein D52 [TPD52], serpin H1 [SERPH], and elongation factor 1-delta [EF1D]). Moreover, 5 of these 7 proteins belonged to a network of predicted interacting proteins (ACTG, UBP5, PSB6, TPD52, and EF1D). This study confirms and provides molecular bases of some earlier observations of effects in vitro of MMF compared to older immunosuppressant (i.e. Cyclosporine A, azathioprine, and methylprednisolone) on reduction of features associated with EMT ${ }^{[28]}$.

Erythropoietin (EPO) analogue - EPO is a hematopoietic hormone produced mainly by adult kidneys and has been routinely used in clinic for nearly 20 year to treat anemia. Apart from its erythropoietic effects, EPO also exhibits powerful tissue-protective effects in AKI induced by I/R. However this observation has not been extended to the clinic due to the short half-life of EPO and increased risk of thrombosis. A novel conformationally constrained cyclized helix B peptide (CHBP) with more than 30 -fold and a 2.5 -fold-longer half-life than EPO in human plasma and hepatocytes, respectively, was developed. CHBP also exerted potent renoprotective activity and significantly decreases local and systemic inflammation and apoptosis in the kidney ${ }^{[29]}$. To obtain improved insight of the effects of CHBP before potential clinical translation, Yang and colleagues studied its effect on the renal tissue proteome in a mouse AKI model ${ }^{[30]}$. The 139 differently expressed proteins were mapped to 8 significant biological pathways. The oxidative phosphorylation pathway was shown to be the most important pathway in CHBP-mediated renoprotection. The major proteins enriched in the oxidative phosphorylation pathway elicited by CHBP were NADH-ubiquinone oxidoreductase Fe-S protein 6 (NDUFS6), alpha-aminoadipic semialdehyde synthase (AASS) and ATPbinding cassette sub family $D$ member 3 ( $A B C D 3)$. Modification of expression changes of these proteins was validated by RT-qPCR and immunostaining in mouse kidneys. Oxidative phosphorylation is associated with mitochondrial stress. NAD+ and NADH play crucial roles in a variety of biological 
processes including energy metabolism, mitochondrial functions, and gene expression. Studies have indicated that NAD+ administration can profoundly decrease oxidative cell death in ischemic organ injury. CHBP restored reduced NAD+ in I/R kidneys associated to improved renal function that might thus be due to its effects on NDUFS6, AASS and ABCD3. The trend of expression of these three proteins was similar in transplanted human kidneys displaying acute tubular necrosis. Overall this study thus provides preclinical evidence of the validity of this new EPO analog in treatment of AKI.

iv) Improving the translational value of preclinical research using proteome-based approaches in diabetic kidney disease

Preclinical testing is essential in the drug discovery process. However, although positive drug responses are often observed in preclinical models, this is only rarely transferable to the human situation. This is probably due to the fact that models imperfectly recapitulate human disease, a situation applicable in nephrology where models are far from perfect ${ }^{[31]}$, e.g. use of young animals in models of CKD while in the human situation CKD is mostly found in the elderly population or the very controlled sanitary situation in animal facilities in contrast to the human situation exposed to many environmental stimuli. In addition, it is also very likely that this low translatability is due to the fact that often only limited aspects of the disease are assessed during drug testing, e.g. monitoring of single biomarkers fails to faithfully describe complex disease phenotypes ${ }^{[32]}$. Multi-peptide panels obtained by peptidomics analysis have shown the potential to comprehensively define adult ${ }^{[33,34]}$, pediatric ${ }^{[35]}$ and prenatal ${ }^{[36]}$ human kidney disease and therefore could also likely be used to improve drug evaluation in preclinical models.

Proof of concept of the improved value of exploiting multimolecular similarity between human disease and animal models has been assessed in the context of diabetic nephropathy (Figure 2) ${ }^{[37]}$. Analysis of the urinary peptide content showed that among the 92 urinary peptides associated with type 2 diabetic nephropathy mice, 21 displayed a high similarity with 273 urinary peptide markers of diabetic nephropathy in human. These 21 orthologue peptides may reflect molecular 
mechanisms of disease similar in mice and human, and more importantly reject responses that are only observed in the preclinical model system, and very likely irrelevant in human disease. The 21 peptides were next combined in a humanized peptide classifier. This so-called "humanized readout" identified correctly mice with diabetic nephropathy compared to healthy mice, and captured the difference between standard-of-care (i.e. renin angiotensin system inhibitors (RASi)) drug response by identifying RASi-treated and untreated mice with diabetic nephropathy. In addition, the model of 21 peptides was validated in a human cohort of diabetic patients with and without the diabetic nephropathy, achieving a sensitivity of $81 \%$ and specificity of $59 \%$ which is remarkable given the reduction from the full human classifier initially composed of 273 peptides.

In a comparable analysis, but with the aim to determine the similarity of a rat model with human cardiovascular disease (CVD) or CKD, the urinary peptidome of Zucker diabetic fatty (ZDF) rats was investigated by Siwy et al. ${ }^{[38]}$. Urinary peptide modifications specific for diabetes-associated complications in ZDF rats were studied by comparison to lean control animals. Multimolecular similarity of these changes was next assessed by comparison with previously validated human CVD ${ }^{[39]}$ and CKD ${ }^{[33]}$ markers. This evaluation suggested that the ZDF model, based on urinary proteome analysis, is very similar and suitable for studies on CVD. However it indicated poor comparability of the model to human CKD while this model is frequently used as a model of chronic kidney disease.

Lastly, comparative urinary peptidome analysis was also used to assess the similarity of wild type (C57BL/6) mice with long-term metabolic syndrome with urinary peptidome data of human diabetic nephropathy. In this long-term metabolic syndrome model, induced by an eight months high fat and fructose diet (HFFD), renal injury was minimal as determined by analysis of kidney structure and function utilizing electron microscopy and GFR measurements. Interestingly this was confirmed by the analysis of the urinary peptidome where, based on peptide orthologs, the model was similar to urinary peptides of type 2 diabetic patients without diabetic nephropathy and not resembling type 2 diabetic patients with diabetic nephropathy ${ }^{[40]}$. 
A recent study, not included in our survey, expands on this concept of using proteome analysis for the determination of similarity, but in this case downstream of the animal models (i.e. focusing on the suitability of cell lines representing the in vivo situation). Rinschen et al., showed that proteomic profile of podocytes directly obtained from mice did not match with frequently used immortalized mouse podocyte culture cell lines. In these cell lines proteins involved in stress fiber formation were among the most strongly dysregulated processes not observed in the freshly isolated podocytes. The authors hypothesized that this could be due to the stiffness of the cell culture dish. Indeed, when transferring those cells on a soft matrix a major shift of the proteome towards the freshly isolated podocyte proteome was observed. However, major differences remained between the cell lines and the freshly isolated podocytes remained ${ }^{[41]}$.

\section{Conclusion - our take}

Taken together, it appears that the most valid contribution of preclinical proteome-based studies in nephrology is the evaluation of drug efficacy and insight in drug mechanisms. Improved modelselection and -readout based on protein signatures identical in preclinical kidney disease models and human disease could lead to more efficient preselection of novel drugs that potentially will work in the human setting and to improve translational value. Study of (novel) drug mechanisms in those preclinical models might also significantly contribute to implementation of a new drug in the clinic (e.g. novel application of MMF or validity of novel EPO analog). In contrast, studies aiming for the discovery of biomarkers for early detection of disease with such preclinical proteome-based studies appear more controversial. Most studies initially focusing on novel (non-invasive) early detection of kidney disease did not hold up in follow-up human studies or were not further pursued. In addition, most studies identified potential markers that were already previously incriminated in renal disease (EGF, fetuin-A, regucalcin, nestin) and were not specific (e.g. markers of both AKI and CKD). The latter might also be due to the fact that in animal models AKI and CKD are mostly single entities, while in human disease both are often intertwined. It therefore seems that preclinical models should not be 
used anymore as the start for proteome-based studies aiming the identification of early biomarkers of kidney disease. Especially in renal disease where urine is an abundant source of biomarkers of diseases of the kidney and the urinary tract ${ }^{[42]}$, it appears that the focus should be on human material based discovery studies.

\section{Acknowledgments}

This work was supported by grants from the "Fondation pour la Recherche Médicale" (grant number DEQ20170336759) and from the European Union's Horizon 2020 research and innovation programme under the Marie Skłodowska-Curie grant agreement No 764474, acronym CaReSyAn.

\section{Conflict of interest statement}

The authors do not declare a conflict of interest. 


\section{References}

[1] M. Rabe, F. Schaefer, Nephron 2016, 133, 53.

[2] H. Chen, L. W. Busse, Kidney Int Rep 2017, 2, 785.

[3] H. M. Kok, L. L. Falke, R. Goldschmeding, T. Q. Nguyen, Nature reviews. Nephrology 2014, 10, 700.

[4] B. B. Betz, S. J. Jenks, A. D. Cronshaw, D. J. Lamont, C. Cairns, J. R. Manning, J. Goddard, D. J. Webb, J. J. Mullins, J. Hughes, S. McLachlan, M. W. J. Strachan, J. F. Price, B. R. Conway, Kidney Int 2016, 89, 1125.

[5] J. Klein, J. L. Bascands, B. Buffin-Meyer, J. Schanstra, Kidney Int 2016, 89, 1125.

[6] N. Nowak, J. Skupien, A. M. Smiles, M. Yamanouchi, M. A. Niewczas, A. T. Galecki, K. L. Duffin, M. D. Breyer, N. Pullen, J. V. Bonventre, A. S. Krolewski, Kidney Int 2018, 93, 1198.

[7] I. Zubiri, M. Posada-Ayala, A. Benito-Martin, A. S. Maroto, M. Martin-Lorenzo, P. CannataOrtiz, F. de la Cuesta, L. Gonzalez-Calero, M. G. Barderas, B. Fernandez-Fernandez, A. Ortiz, F. Vivanco, G. Alvarez-Llamas, Transl Res 2015, 166, 474.

[8] M. Yamaguchi, Int J Mol Med 2015, 36, 1191.

[9] H. Zhou, T. Pisitkun, A. Aponte, P. S. Yuen, J. D. Hoffert, H. Yasuda, X. Hu, L. Chawla, R. F. Shen, M. A. Knepper, R. A. Star, Kidney Int 2006, 70, 1847.

[10] W. Zhang, L. Zhang, Y. X. Chen, Y. Y. Xie, Y. F. Zou, M. J. Zhang, Y. H. Gao, Y. Liu, Q. Zhao, Q. H. Huang, N. Chen, Am J Nephrol 2014, 39, 110.

[11] N. Piazzon, F. Bernet, L. Guihard, W. N. Leonhard, S. Urfer, D. Firsov, H. Chehade, B. Vogt, S. Piergiovanni, D. J. Peters, O. Bonny, D. B. Constam, Journal of translational medicine 2015, 13, 103.

[12] M. Ombrellino, H. Wang, H. Yang, M. Zhang, J. Vishnubhakat, A. Frazier, L. A. Scher, S. G. Friedman, K. J. Tracey, Shock 2001, 15, 181.

[13] C. Schafer, A. Heiss, A. Schwarz, R. Westenfeld, M. Ketteler, J. Floege, W. Muller-Esterl, T. Schinke, W. Jahnen-Dechent, The Journal of clinical investigation 2003, 112, 357.

[14] B. Pecovnik-Balon, Ther Apher Dial 2005, 9, 208; M. Ketteler, P. Bongartz, R. Westenfeld, J. E. Wildberger, A. H. Mahnken, R. Bohm, T. Metzger, C. Wanner, W. Jahnen-Dechent, J. Floege, Lancet 2003, 361, 827.

[15] J. Chen, S. Boyle, M. Zhao, W. Su, K. Takahashi, L. Davis, M. Decaestecker, T. Takahashi, M. D. Breyer, C. M. Hao, J Am Soc Nephrol 2006, 17, 1283.

[16] P. S. Thorner, M. Ho, V. Eremina, Y. Sado, S. Quaggin, J Am Soc Nephrol 2008, 19, 495.

[17] M. Zivotic, R. Bogdanovic, A. Peco-Antic, D. Paripovic, N. Stajic, J. Vjestica, S. Cirovic, G. Trajkovic, J. Markovic-Lipkovski, Pediatr Nephrol 2015, 30, 79.

[18] M. Tomioka, K. Hiromura, T. Sakairi, S. Takeuchi, A. Maeshima, Y. Kaneko, T. Kuroiwa, T. Takeuchi, Y. Nojima, Nephrology 2010, 15, 568.

[19] B. Maddens, B. Ghesquiere, R. Vanholder, D. Demon, J. Vanmassenhove, K. Gevaert, E. Meyer, Mol Cell Proteomics 2012, 11, M111 013094.

[20] J. De Loor, J. Decruyenaere, K. Demeyere, L. Nuytinck, E. A. Hoste, E. Meyer, Critical care 2016, 20, 38.

[21] J. De Loor, I. Herck, K. Francois, A. Van Wesemael, L. Nuytinck, E. Meyer, E. A. J. Hoste, Ann Intensive Care 2017, 7, 24.

[22] C. H. He, C. G. Lee, C. S. Dela Cruz, C. M. Lee, Y. Zhou, F. Ahangari, B. Ma, E. L. Herzog, S. A. Rosenberg, Y. Li, A. M. Nour, C. R. Parikh, I. Schmidt, Y. Modis, L. Cantley, J. A. Elias, Cell Rep 2013, 4, 830.

[23] Y. Zhou, H. Peng, H. Sun, X. Peng, C. Tang, Y. Gan, X. Chen, A. Mathur, B. Hu, M. D. Slade, R. R. Montgomery, A. C. Shaw, R. J. Homer, E. S. White, C. M. Lee, M. W. Moore, M. Gulati, C. G. Lee, J. A. Elias, E. L. Herzog, Science translational medicine 2014, 6, 240 ra76.

[24] T. A. Montgomery, L. Xu, S. Mason, A. Chinnadurai, C. G. Lee, J. A. Elias, L. G. Cantley, J Am Soc Nephrol 2017, 28, 3218.

[25] M. C. Villarroel, M. Hidalgo, A. Jimeno, Drugs Today (Barc) 2009, 45, 521. 
[26] D. T. Petrova, F. Brehmer, F. C. Schultze, A. R. Asif, O. Gross, M. Oellerich, G. Brandhorst, Pathobiology 2011, 78, 162.

[27] S. Lovisa, M. Zeisberg, R. Kalluri, Trends Endocrinol Metab 2016, 27, 681.

[28] J. W. Copeland, B. W. Beaumont, M. J. Merrilees, H. L. Pilmore, Transplantation 2007, 83,

809.

[29] C. Yang, Z. Xu, Z. Zhao, L. Li, T. Zhao, D. Peng, M. Xu, R. Rong, Y. Q. Long, T. Zhu, Biochimica et biophysica acta 2014, 1842, 2306.

[30] C. Yang, J. Liu, L. Li, M. Hu, Y. Long, X. Liu, T. Zhu, X. Huang, S. Zhao, S. Liu, R. Rong, Sci Rep 2015, 5, 18045.

[31] G. J. Becker, T. D. Hewitson, Nephrol Dial Transplant 2013, 28, 2432.

[32] J. Klein, J. L. Bascands, H. Mischak, J. P. Schanstra, Kidney Int 2016, 89, 539.

[33] D. M. Good, P. Zuerbig, A. Argiles, H. W. Bauer, G. Behrens, J. J. Coon, M. Dakna, S. Decramer, C. Delles, A. F. Dominiczak, J. H. H. Ehrich, F. Eitner, D. Fliser, M. Frommberger, A. Ganser, M. A. Girolami, I. Golovko, W. Gwinner, M. Haubitz, S. Herget-Rosenthal, J. Jankowski, H. Jahn, G. Jerums, B. A. Julian, M. Kellmann, V. Kliem, W. Kolch, A. S. Krolewski, M. Luppi, Z. Massy, M. Melter, C. Neusuess, J. Novak, K. Peter, K. Rossing, H. Rupprecht, J. P. Schanstra, E. Schiffer, J.-U. Stolzenburg, L. Tarnow, D. Theodorescu, V. Thongboonkerd, R. Vanholder, E. M. Weissinger, H. Mischak, P. SchmittKopplin, Molecular \& Cellular Proteomics 2010, 9, 2424.

[34] J. P. Schanstra, P. Zurbig, A. Alkhalaf, A. Argiles, S. J. Bakker, J. Beige, H. J. Bilo, C. Chatzikyrkou, M. Dakna, J. Dawson, C. Delles, H. Haller, M. Haubitz, H. Husi, J. Jankowski, G. Jerums, N. Kleefstra, T. Kuznetsova, D. M. Maahs, J. Menne, W. Mullen, A. Ortiz, F. Persson, P. Rossing, P. Ruggenenti, I. Rychlik, A. L. Serra, J. Siwy, J. Snell-Bergeon, G. Spasovski, J. A. Staessen, A. Vlahou, H. Mischak, R. Vanholder, J Am Soc Nephrol 2015, 26, 1999.

[35] J. Drube, P. Zurbig, E. Schiffer, E. Lau, B. Ure, S. Gluer, M. Kirschstein, L. Pape, S. Decramer, J. L. Bascands, J. P. Schanstra, H. Mischak, J. H. Ehrich, Pediatr Nephrol 2010, 25, 1673.

[36] J. Klein, C. Lacroix, C. Caubet, J. Siwy, P. Zuerbig, M. Dakna, F. Muller, B. Breuil, A. Stalmach, W. Mullen, H. Mischak, F. Bandin, B. Monsarrat, J.-L. Bascands, S. Decramer, J. P. Schanstra, Science translational medicine 2013, 5.

[37] J. Klein, A. Ramirez-Torres, A. Ericsson, Y. Huang, B. Breuil, J. Siwy, H. Mischak, X. R. Peng, J. L. Bascands, J. P. Schanstra, Kidney Int 2016, 90, 1045.

[38] J. Siwy, C. Zoja, J. Klein, A. Benigni, W. Mullen, B. Mayer, H. Mischak, J. Jankowski, R. Stevens, A. Vlahou, S. Kossida, P. Perco, F. H. Bahlmann, PloS one 2012, 7, e51334.

[39] C. Delles, E. Schiffer, C. von Zur Muhlen, K. Peter, P. Rossing, H. H. Parving, J. A. Dymott, U. Neisius, L. U. Zimmerli, J. K. Snell-Bergeon, D. M. Maahs, R. E. Schmieder, H. Mischak, A. F. Dominiczak, Journal of hypertension 2010, 28, 2316.

[40] R. Dissard, J. Klein, C. Caubet, B. Breuil, J. Siwy, J. Hoffman, L. Sicard, L. Ducasse, S. Rascalou, B. Payre, M. Buleon, W. Mullen, H. Mischak, I. Tack, J. L. Bascands, B. Buffin-Meyer, J. P. Schanstra, PloS one 2013, 8, e76703.

[41] M. M. Rinschen, M. Godel, F. Grahammer, S. Zschiedrich, M. Helmstadter, O. Kretz, M. Zarei, D. A. Braun, S. Dittrich, C. Pahmeyer, P. Schroder, C. Teetzen, H. Gee, G. Daouk, M. Pohl, E. Kuhn, B. Schermer, V. Kuttner, M. Boerries, H. Busch, M. Schiffer, C. Bergmann, M. Kruger, F. Hildebrandt, J. Dengjel, T. Benzing, T. B. Huber, Cell Rep 2018, 23, 2495.

[42] S. Decramer, A. Gonzalez de Peredo, B. Breuil, H. Mischak, B. Monsarrat, J. L. Bascands, J. P. Schanstra, Mol Cell Proteomics 2008, 7, 1850. 


\section{Figure legends}

Figure 1: Ingenuity Pathway Analysis of disease networks of proteins identified in preclinical models of AKI and CKD using proteome analysis (tissue and urine). A) The top 1 disease network in CKD was identified as cardiovascular disease. B) The top 1 functional network in AKI was identified as free radical scavenging.

Figure 2: The concept of the development of humanized preclinical models based on multimolecular readouts. A number of urinary peptide-based models are available for a variety of human diseases. These models are composed in general of several hundreds of peptides. Humanized peptide models are obtained by analyzing the urinary peptidome of animal models of disease followed by identification of peptides similar in mice and humans " orthologues ", leaving aside nonhuman disease relevant peptides " mouse only peptides ". These orthologue peptides are combined in classifiers allowing a "humanized" prediction of disease and drug response thereby increasing the translatability of the observed effects. Adapted from Klein et al. ${ }^{[37]}$, with permission. 
Tables

Table 1: Proteins mentioned in the abstracts of the 68 selected studies as being modified in preclinical models of AKI.

\begin{tabular}{|c|c|c|c|}
\hline \multirow{16}{*}{$\sum_{\substack{Z \\
\hdashline}}^{3}$} & Tyrosine-protein kinase JAK** & $\begin{array}{l}\text { Non-receptor tyrosine kinase involved in various processes such as cell growth, } \\
\text { development, differentiation or histone modifications. }\end{array}$ & Nucleus \\
\hline & $\begin{array}{l}\text { Signal transducer and activator of } \\
\text { transcription** }\end{array}$ & $\begin{array}{l}\text { Signal transducer and activator of transcription that mediates signaling by type I IFNs } \\
\text { (IFN-alpha and IFN-beta). }\end{array}$ & Nucleus \\
\hline & Calbindin & $\begin{array}{l}\text { Buffers cytosolic calcium. May stimulate a membrane Ca2+-ATPase and a 3',5'-cyclic } \\
\text { nucleotide phosphodiesterase. }\end{array}$ & $\begin{array}{l}\text { Cytosol, Extracellular } \\
\text { exosome, Nucleus }\end{array}$ \\
\hline & Basigin & $\begin{array}{l}\text { Plays pivotal roles in spermatogenesis, embryo implantation, neural network } \\
\text { formation and tumor progression. Stimulates adjacent fibroblasts to produce matrix } \\
\text { metalloproteinases (MMPS). }\end{array}$ & Plasma membrane \\
\hline & Fizzy-related protein homolog & $\begin{array}{l}\text { Substrate-specific adapter for the anaphase promoting complex/cyclosome (APC/C) } \\
\text { E3 ubiquitin-protein ligase complex. }\end{array}$ & Nucleus \\
\hline & Pro-epidermal growth factor & $\begin{array}{l}\text { EGF stimulates the growth of various epidermal and epithelial tissues in vivo and in } \\
\text { vitro and of some fibroblasts in cell culture. }\end{array}$ & Secreted \\
\hline & Glutathione S-transferase P & $\begin{array}{l}\text { Conjugation of reduced glutathione to a wide number of exogenous and endogenous } \\
\text { hydrophobic electrophiles. }\end{array}$ & $\begin{array}{l}\text { Nucleus, Mitochondrion, } \\
\text { Cytoplasm }\end{array}$ \\
\hline & Hepcidin & $\begin{array}{l}\text { Liver-produced hormone that constitutes the main circulating regulator of iron } \\
\text { absorption and distribution across tissues. }\end{array}$ & Secreted \\
\hline & Heat shock cognate $71 \mathrm{kDa}$ protein & $\begin{array}{l}\text { Molecular chaperone implicated in a wide variety of cellular processes, including } \\
\text { protection of the proteome from stress, folding and transport of newly synthesized } \\
\text { polypeptides, activation of proteolysis of misfolded proteins and the formation and } \\
\text { dissociation of protein complexes. }\end{array}$ & $\begin{array}{l}\text { Plasma membrane, Nucleus, } \\
\text { Cytoplasm }\end{array}$ \\
\hline & Nucleoside diphosphate kinase B & $\begin{array}{l}\text { Major role in the synthesis of nucleoside triphosphates other than ATP. Negatively } \\
\text { regulates Rho activity by interacting with AKAP13/LBC }\end{array}$ & Nucleus, Cytoplasm \\
\hline & $\begin{array}{l}\text { NADH dehydrogenase [ubiquinone] } 1 \text { alpha } \\
\text { subcomplex subunit } 10 .\end{array}$ & $\begin{array}{l}\text { Accessory subunit of the mitochondrial membrane respiratory chain NADH } \\
\text { dehydrogenase (Complex I), that is believed not to be involved in catalysis. }\end{array}$ & Mitochondrion \\
\hline & Podocin & $\begin{array}{l}\text { Plays a role in the regulation of glomerular permeability, acting probably as a linker } \\
\text { between the plasma membrane and the cytoskeleton. }\end{array}$ & $\begin{array}{l}\text { Plasma membrane, } \\
\text { Endoplasmic reticulum }\end{array}$ \\
\hline & $\begin{array}{l}\mathrm{Na}(+) / \mathrm{H}(+) \text { exchange regulatory cofactor } \\
\mathrm{NHE}-\mathrm{RF} 3\end{array}$ & $\begin{array}{l}\text { A scaffold protein that connects plasma membrane proteins and regulatory } \\
\text { components, regulating their surface expression in epithelial cells apical domains. }\end{array}$ & Plasma membrane \\
\hline & Phosphoglycerate kinase** & A glycolytic enzyme (PGK-1) & Cytoplasm \\
\hline & Phosphoserine phosphatase ${ }^{* *}$ & Catalyzes the last step in the biosynthesis of serine from carbohydrates. & Cytosol \\
\hline & Regucalcin & $\begin{array}{l}\text { Gluconolactonase with low activity towards other sugar lactones, including } \\
\text { gulonolactone and galactonolactone. }\end{array}$ & Cytoplasm \\
\hline \multirow{15}{*}{$\stackrel{9}{9}$} & $\begin{array}{l}\text { 2-amino-3-carboxymuconate-6- } \\
\text { semialdehyde decarboxylase }\end{array}$ & $\begin{array}{l}\text { Converts alpha-amino-beta-carboxymuconate-epsilon-semialdehyde (ACMS) to alpha- } \\
\text { aminomuconate semialdehyde (AMS). ACMS can be converted non-enzymatically to } \\
\text { quinolate (QA), a key precursor of NAD, and a potent endogenous excitotoxin of } \\
\text { neuronal cells which is implicated in the pathogenesis of various neurodegenerative } \\
\text { disorders. }\end{array}$ & Cytosol \\
\hline & Actin, aortic smooth muscle & $\begin{array}{l}\text { Actins are highly conserved proteins that are involved in various types of cell motility } \\
\text { and are ubiquitously expressed in all eukaryotic cells. }\end{array}$ & Cytoskeleton \\
\hline & Alpha-2-HS-glycoprotein & $\begin{array}{l}\text { Promotes endocytosis, possesses opsonic properties and influences the mineral phase } \\
\text { of bone. Shows affinity for calcium and barium ions. }\end{array}$ & Secreted \\
\hline & Serum albumin & $\begin{array}{l}\text { Serum albumin, the main protein of plasma, has a good binding capacity for water, } \\
\mathrm{Ca} 2+, \mathrm{Na}+, \mathrm{K}+\text {, fatty acids, hormones, bilirubin and drugs. }\end{array}$ & Secreted \\
\hline & Caldesmon & $\begin{array}{l}\text { Actin- and myosin-binding protein implicated in the regulation of actomyosin } \\
\text { interactions in smooth muscle and nonmuscle cells (could act as a bridge between } \\
\text { myosin and actin filaments). }\end{array}$ & Cytoskeleton \\
\hline & Chitinase-3-like protein 1 & $\begin{array}{l}\text { Carbohydrate-binding lectin with a preference for chitin. Has no chitinase activity. } \\
\text { May play a role in tissue remodeling and in the capacity of cells to respond to and } \\
\text { cope with changes in their environment. }\end{array}$ & $\begin{array}{l}\text { Endoplasmic reticulum, } \\
\text { Cytoplasm }\end{array}$ \\
\hline & Acidic mammalian chitinase & $\begin{array}{l}\text { Degrades chitin and chitotriose. May participate in the defense against nematodes, } \\
\text { fungi and other pathogens. }\end{array}$ & Secreted, Cytoplasm \\
\hline & Kidney aminoacylase IB & n.a. & n.a. \\
\hline & Cytochrome c oxidase subunit 5B & $\begin{array}{l}\text { This protein is one of the nuclear-coded polypeptide chains of cytochrome c oxidase, } \\
\text { the terminal oxidase in mitochondrial electron transport. }\end{array}$ & Mitochondrion \\
\hline & Ceruloplasmin & $\begin{array}{l}\text { Ceruloplasmin is a blue, copper-binding ( } 6-7 \text { atoms per molecule) glycoprotein. It has } \\
\text { ferroxidase activity oxidizing Fe } 2+\text { to Fe } 3+\text { without releasing radical oxygen species. It } \\
\text { is involved in iron transport across the cell membrane. }\end{array}$ & Secreted \\
\hline & Alpha-crystallin B chain & May contribute to the transparency and refractive index of the lens. & Nucleus, Cytoplasm \\
\hline & Catenin beta-1 & Key downstream component of the canonical Wnt signaling pathway. & $\begin{array}{l}\text { Cytoskeleton, Nucleus, } \\
\text { Cytoplasm, Plasma } \\
\text { membrane }\end{array}$ \\
\hline & Fumarylacetoacetase & $\begin{array}{l}\text { This protein is involved in synthesizes of acetoacetate and fumarate from L- } \\
\text { phenylalanine. }\end{array}$ & Cytosol, Secreted \\
\hline & Fibroblast growth factor receptor 1 & $\begin{array}{l}\text { Tyrosine-protein kinase that acts as cell-surface receptor for fibroblast growth factors } \\
\text { and plays an essential role in the regulation of embryonic development, cell } \\
\text { proliferation, differentiation and migration. }\end{array}$ & $\begin{array}{l}\text { Plasma membrane, } \\
\text { Nucleus, Cytosol }\end{array}$ \\
\hline & Vitamin D-binding protein & $\begin{array}{l}\text { Involved in vitamin D transport and storage, scavenging of extracellular G-actin, } \\
\text { enhancement of the chemotactic activity of C5 alpha for neutrophils in inflammation }\end{array}$ & Secreted \\
\hline
\end{tabular}




\begin{tabular}{|c|c|c|}
\hline & and macrophage activation. & \\
\hline Lactoylglutathione lyase & $\begin{array}{l}\text { Catalyzes the conversion of hemimercaptal, formed from methylglyoxal and } \\
\text { glutathione, to S-lactoylglutathione. }\end{array}$ & $\begin{array}{l}\text { Cytosol, Nucleus, Plasma } \\
\text { Membrane }\end{array}$ \\
\hline Glutamate receptor ionotropic, NMDA 1 & $\begin{array}{l}\text { Component of NMDA receptor complexes that function as heterotetrameric, ligand- } \\
\text { gated ion channels with high calcium permeability and voltage-dependent sensitivity } \\
\text { to magnesium. }\end{array}$ & Plasma membrane \\
\hline Glycogen synthase kinase-3 beta & $\begin{array}{l}\text { Constitutively active protein kinase that acts as a negative regulator in the hormonal } \\
\text { control of glucose homeostasis, Wnt signaling and regulation of transcription factors } \\
\text { and microtubules. }\end{array}$ & $\begin{array}{l}\text { Nucleus, Plasma } \\
\text { membrane, Cytoplasm }\end{array}$ \\
\hline Heat shock cognate $71 \mathrm{kDa}$ protein & $\begin{array}{l}\text { Molecular chaperone implicated in a wide variety of cellular processes, including } \\
\text { protection of the proteome from stress, folding and transport of newly synthesized } \\
\text { polypeptides, activation of proteolysis of misfolded proteins and the formation and } \\
\text { dissociation of protein complexes. }\end{array}$ & $\begin{array}{l}\text { Nucleus, Plasma } \\
\text { membrane, Cytoplasm }\end{array}$ \\
\hline Microtubule-associated proteins** & $\begin{array}{l}\text { Ubiquitin-like modifier involved in formation of autophagosomal vacuoles } \\
\text { (autophagosomes). }\end{array}$ & $\begin{array}{l}\text { Cytoskeleton, } \\
\text { Autophagosome membrane }\end{array}$ \\
\hline Mitogen-activated protein kinases** & $\begin{array}{l}\text { MAPKs are involved in directing cellular responses to a diverse array of stimuli, such } \\
\text { as mitogens, osmotic stress, heat shock and proinflammatory cytokines. }\end{array}$ & \\
\hline Neutrophil gelatinase-associated lipocalin & $\begin{array}{l}\text { Iron-trafficking protein involved in multiple processes such as apoptosis, innate } \\
\text { immunity and renal development. }\end{array}$ & Secreted \\
\hline Methylmalonyl-CoA mutase & $\begin{array}{l}\text { Involved in the degradation of several amino acids, odd-chain fatty acids and } \\
\text { cholesterol via propionyl-CoA to the tricarboxylic acid cycle. }\end{array}$ & Mitochondrion \\
\hline Nestin & $\begin{array}{l}\text { Promotes the disassembly of phosphorylated vimentin intermediate filaments (IF) } \\
\text { during mitosis. }\end{array}$ & Cytoskeleton, cytoplasm \\
\hline 2-oxoglutarate dehydrogenase & $\begin{array}{l}\text { 2-oxoglutarate dehydrogenase (E1) component of the 2-oxoglutarate dehydrogenase } \\
\text { complex, which mediates the decarboxylation of alpha-ketoglutarate. }\end{array}$ & Mitochondrion, Nucleus \\
\hline Protein disulfide-isomerase & $\begin{array}{l}\text { This multifunctional protein catalyzes the formation, breakage and rearrangement of } \\
\text { disulfide bonds. }\end{array}$ & $\begin{array}{l}\text { Endoplasmic reticulum, } \\
\text { Plasma membrane }\end{array}$ \\
\hline Peroxiredoxin-1 and -6 & $\begin{array}{l}\text { Thiol-specific peroxidase that catalyzes the reduction of hydrogen peroxide and } \\
\text { organic hydroperoxides to water and alcohols, respectively. }\end{array}$ & $\begin{array}{l}\text { Cytoplasm ( PRDX1 and 6), } \\
\text { Lysosome (PRDX6) }\end{array}$ \\
\hline Proteasome subunit beta type-3 & $\begin{array}{l}\text { Component of the } 20 \mathrm{~S} \text { core proteasome complex involved in the proteolytic } \\
\text { degradation of most intracellular proteins. }\end{array}$ & Nucleus, Cytoplasm \\
\hline Protein S100-A4 & Calcium binding. & $\begin{array}{l}\text { Extracellular region or } \\
\text { secreted, Nucleus }\end{array}$ \\
\hline Alpha-1-antitrypsin & $\begin{array}{l}\text { Inhibitor of serine proteases. Its primary target is elastase, but it also has a moderate } \\
\text { affinity for plasmin and thrombin. Irreversibly inhibits trypsin, chymotrypsin and } \\
\text { plasminogen activator. }\end{array}$ & $\begin{array}{l}\text { Endoplasmic reticulum, } \\
\text { Secreted, Extracellular } \\
\text { matrix }\end{array}$ \\
\hline $\begin{array}{l}\text { Succinate--CoA ligase [GDP-forming] subunit } \\
\text { beta }\end{array}$ & $\begin{array}{l}\text { GTP-specific succinyl-CoA synthetase functions in the citric acid cycle (TCA), coupling } \\
\text { the hydrolysis of succinyl-CoA to the synthesis of GTP and thus represents the only } \\
\text { step of substrate-level phosphorylation in the TCA. }\end{array}$ & Mitochondrion \\
\hline Serotransferrin & $\begin{array}{l}\text { Transferrins are iron binding transport proteins which can bind two Fe } 3+\text { ions in } \\
\text { association with the binding of an anion, usually bicarbonate. }\end{array}$ & Secreted \\
\hline Hamartin & $\begin{array}{l}\text { In complex with TSC2, inhibits the nutrient-mediated or growth factor-stimulated } \\
\text { phosphorylation of S6K1 and EIF4EBP1 by negatively regulating mTORC1 signaling. }\end{array}$ & n.a. \\
\hline Thioredoxin & $\begin{array}{l}\text { Participates in various redox reactions through the reversible oxidation of its active } \\
\text { center dithiol to a disulfide and catalyzes dithiol-disulfide exchange reactions (By } \\
\text { similarity). }\end{array}$ & $\begin{array}{l}\text { Secreted, Nucleus, } \\
\text { Cytoplasm }\end{array}$ \\
\hline Uromodulin & $\begin{array}{l}\text { Functions in biogenesis and organization of the apical membrane of epithelial cells of } \\
\text { the thick ascending limb of Henle's loop. }\end{array}$ & Plasma membrane, Secreted \\
\hline Vimentin & $\begin{array}{l}\text { Vimentins are class-III intermediate filaments found in various non-epithelial cells, } \\
\text { especially mesenchymal cells. }\end{array}$ & $\begin{array}{l}\text { Cytoskeleton, Nucleus, } \\
\text { Cytoplasm }\end{array}$ \\
\hline
\end{tabular}

*, From Uniprot ; ${ }^{* *}$, in those cases the generic name of a group of molecules has been used due to the fact that specific group partners were not identified in the experiments (eg MAPK and not ERK1/ERK2); n.a., not available. 
Table 2: Proteins mentioned in the abstracts of the 68 selected studies as being modified in

preclinical models of CKD. Proteins were found to be modified in the same direction in multiple

studies are indicated by [seen modified in number studies]x.

\begin{tabular}{|c|c|c|c|}
\hline \multirow{18}{*}{$\sum_{\substack{Z \\
\hdashline}}^{3}$} & Adenylate kinase 4 & $\begin{array}{l}\text { Involved in maintaining the homeostasis of cellular nucleotides by catalyzing the interconversion } \\
\text { of nucleoside phosphates. }\end{array}$ & Mitochondrion \\
\hline & Annexin A4 & $\begin{array}{l}\text { Calcium/phospholipid-binding protein which promotes membrane fusion and is involved in } \\
\text { exocytosis. }\end{array}$ & $\begin{array}{l}\text { Secreted, Nucleus, Plasma } \\
\text { membrane }\end{array}$ \\
\hline & Aquaporin-1 & $\begin{array}{l}\text { Forms a water-specific channel that provides the plasma membranes of red cells and kidney } \\
\text { proximal tubules with high permeability to water, thereby permitting water to move in the } \\
\text { direction of an osmotic gradient. }\end{array}$ & Plasma membrane \\
\hline & ATP synthase subunit beta & $\begin{array}{l}\text { Mitochondrial membrane ATP synthase (F1F0 ATP synthase or Complex V) produces ATP from } \\
\text { ADP in the presence of a proton gradient across the membrane which is generated by electron } \\
\text { transport complexes of the respiratory chain. }\end{array}$ & Mitochondrion \\
\hline & $\begin{array}{l}\text { Dihydropyrimidinase-related } \\
\text { protein } 2\end{array}$ & $\begin{array}{l}\text { Plays a role in neuronal development and polarity, as well as in axon growth and guidance, } \\
\text { neuronal growth cone collapse and cell migration. }\end{array}$ & Cytoskeleton, Cytosol \\
\hline & $\begin{array}{l}\text { Pro-epidermal growth factor } \\
{[2 \mathrm{x}]}\end{array}$ & $\begin{array}{l}\text { EGF stimulates the growth of various epidermal and epithelial tissues in vivo and in vitro and of } \\
\text { some fibroblasts in cell culture. }\end{array}$ & Secreted \\
\hline & Ezrin & Probably involved in connections of major cytoskeletal structures to the plasma membrane. & $\begin{array}{l}\text { Cytoskeleton, Plasma } \\
\text { membrane }\end{array}$ \\
\hline & $\begin{array}{l}\text { Glutamate--cysteine ligase } \\
\text { regulatory subunit }\end{array}$ & $\begin{array}{l}\text { This protein is involved in step } 1 \text { of the subpathway that synthesizes glutathione from L-cysteine } \\
\text { and L-glutamate. }\end{array}$ & Cytosol \\
\hline & $\begin{array}{l}\text { Hydroxyacyl-coenzyme A } \\
\text { dehydrogenase }\end{array}$ & Plays an essential role in the mitochondrial beta-oxidation of short chain fatty acids. & Mitochondrion \\
\hline & Kin of IRRE-like protein 1 & Plays a significant role in the normal development and function of the glomerular permeability. & Plasma membrane \\
\hline & Meprin A subunit alpha & $\begin{array}{l}\text { Hydrolysis of protein and peptide substrates preferentially on carboxyl side of hydrophobic } \\
\text { residues. }\end{array}$ & Secreted, plasma membrane \\
\hline & Major urinary protein 1 & Binds pheromones that are released from drying urine of males. & Secreted \\
\hline & Nephrin & Seems to play a role in the development or function of the kidney glomerular filtration barrier. & Plasma membrane \\
\hline & Podocin & $\begin{array}{l}\text { Plays a role in the regulation of glomerular permeability, acting probably as a linker between the } \\
\text { plasma membrane and the cytoskeleton. }\end{array}$ & $\begin{array}{l}\text { Plasma membrane, } \\
\text { Endoplasmic reticulum }\end{array}$ \\
\hline & Prohibitin & Prohibitin inhibits DNA synthesis. It has a role in regulating proliferation. & Mitochondrion \\
\hline & Dihydropteridine reductase & $\begin{array}{l}\text { The product of this enzyme, tetrahydrobiopterin (BH-4), is an essential cofactor for phenylalanine, } \\
\text { tyrosine, and tryptophan hydroxylases. }\end{array}$ & Cytosol, Secreted \\
\hline & Regucalcin & $\begin{array}{l}\text { Gluconolactonase with low activity towards other sugar lactones, including gulonolactone and } \\
\text { galactonolactone. }\end{array}$ & Cytoplasm \\
\hline & $\begin{array}{l}\mathrm{Na}(+) / \mathrm{H}(+) \text { exchange } \\
\text { regulatory cofactor } \mathrm{NHE}-\mathrm{RF} 2\end{array}$ & $\begin{array}{l}\text { Scaffold protein that connects plasma membrane proteins with members of the } \\
\text { ezrin/moesin/radixin family and thereby helps to link them to the actin cytoskeleton and to } \\
\text { regulate their surface expression. }\end{array}$ & Nucleus, Plasma membrane \\
\hline \multirow{20}{*}{ 号 } & $\begin{array}{l}\text { Acyl-coenzyme A thioesterase } \\
1\end{array}$ & $\begin{array}{l}\text { Acyl-CoA thioesterases are a group of enzymes that catalyze the hydrolysis of acyl-CoAs to the } \\
\text { free fatty acid and coenzyme A (CoASH). }\end{array}$ & Cytoplasm \\
\hline & $\begin{array}{l}\text { Actin, gamma-enteric smooth } \\
\text { muscle }\end{array}$ & $\begin{array}{l}\text { Actins are highly conserved proteins that are involved in various types of cell motility and are } \\
\text { ubiquitously expressed in all eukaryotic cells. }\end{array}$ & Cytoskeleton \\
\hline & Alpha-actinin-4 & $\begin{array}{l}\text { F-actin cross-linking protein which is thought to anchor actin to a variety of intracellular } \\
\text { structures. }\end{array}$ & Nucleus, Cytoskeleton \\
\hline & Apoptosis-inducing factor 1 & Functions both as NADH oxidoreductase and as regulator of apoptosis. & Nucleus, Mitochondrion \\
\hline & Retinal dehydrogenase 1 & $\begin{array}{l}\text { Can convert/oxidize retinaldehyde to retinoic acid. Binds free retinal and cellular retinol-binding } \\
\text { protein-bound retinal (By similarity). }\end{array}$ & Cytosol \\
\hline & Aspartoacylase & Catalyzes the deacetylation of $\mathrm{N}$-acetylaspartic acid (NAA) to produce acetate and L-aspartate. & Nucleus, Cytoplasm \\
\hline & Creatine kinase B-type & $\begin{array}{l}\text { Reversibly catalyzes the transfer of phosphate between ATP and various phosphogens (e.g. } \\
\text { creatine phosphate). }\end{array}$ & Cytoplasm \\
\hline & Collagen alpha-1(VI) chain & Collagen VI acts as a cell-binding protein. & Extracellular matrix \\
\hline & Cytochrome c1 & $\begin{array}{l}\text { This is the heme-containing component of the cytochrome b-c1 complex, which accepts electrons } \\
\text { from Rieske protein and transfers electrons to cytochrome } \mathrm{c} \text { in the mitochondrial respiratory } \\
\text { chain. }\end{array}$ & Mitochondrion \\
\hline & $\begin{array}{l}\mathrm{N}(\mathrm{G}), \mathrm{N}(\mathrm{G}) \text {-dimethylarginine } \\
\text { dimethylaminohydrolase } 1\end{array}$ & $\begin{array}{l}\text { Hydrolyzes N(G),N(G)-dimethyl-L-arginine (ADMA) and N(G)-monomethyl-L-arginine (MMA) which } \\
\text { act as inhibitors of NOS. }\end{array}$ & Cytosol, Secreted \\
\hline & Desmin & $\begin{array}{l}\text { Muscle-specific type III intermediate filament essential for proper muscular structure and } \\
\text { function. }\end{array}$ & Plasma membrane, Nucleus \\
\hline & Dipeptidyl peptidase 4 & $\begin{array}{l}\text { Cell surface glycoprotein receptor involved in the costimulatory signal essential for T-cell receptor } \\
\text { (TCR)-mediated T-cell activation. }\end{array}$ & $\begin{array}{l}\text { Secreted, Plasma membrane, } \\
\text { Cell junction }\end{array}$ \\
\hline & Elastin & $\begin{array}{l}\text { ajor structural protein of tissues such as aorta and nuchal ligament, which must expand rapidly } \\
\text { and recover completely. }\end{array}$ & Extracellular matrix \\
\hline & GRB2-related adapter protein & Couples signals from receptor and cytoplasmic tyrosine kinases to the Ras signaling pathway. & Cytosol, Plasma Membrane \\
\hline & $\begin{array}{l}\text { 3-hydroxyisobutyrate } \\
\text { dehydrogenase }\end{array}$ & 3-hydroxy-2-methylpropanoate + NAD+ = 2-methyl-3-oxopropanoate + NADH. & Mitochondrion \\
\hline & $\begin{array}{l}\text { Hydroxymethylglutaryl-CoA } \\
\text { synthase }\end{array}$ & $\begin{array}{l}\text { This enzyme condenses acetyl-CoA with acetoacetyl-CoA to form HMG-CoA, which is the } \\
\text { substrate for HMG-CoA reductase. }\end{array}$ & Mitochondrion \\
\hline & Galectin-1 & Lectin that binds beta-galactoside and a wide array of complex carbohydrates. & Extracellular matrix \\
\hline & Lactadherin & $\begin{array}{l}\text { Plays an important role in the maintenance of intestinal epithelial homeostasis and the promotion } \\
\text { of mucosal healing. }\end{array}$ & Secreted, Membrane \\
\hline & Myosin regulatory light chain 2 & Contractile protein that plays a role in heart development and function (By similarity). & n.a. \\
\hline & Ornithine aminotransferase & This protein is involved in step 1 of the subpathway that synthesizes L-glutamate 5-semialdehyde & Mitochondrion \\
\hline
\end{tabular}




\begin{tabular}{|c|c|c|}
\hline & from L-ornithine. & \\
\hline Periostin & Induces cell attachment and spreading and plays a role in cell adhesion & $\begin{array}{l}\text { Golgi apparatus, Secreted, } \\
\text { Extracellular matrix }\end{array}$ \\
\hline Peroxiredoxin-1 & $\begin{array}{l}\text { Thiol-specific peroxidase that catalyzes the reduction of hydrogen peroxide and organic } \\
\text { hydroperoxides to water and alcohols, respectively. }\end{array}$ & Cytoplasm \\
\hline $\begin{array}{l}\text { cAMP-dependent protein } \\
\text { kinase catalytic subunit beta }\end{array}$ & Mediates cAMP-dependent signaling triggered by receptor binding to GPCRs. & $\begin{array}{l}\text { Nucleus, Plasma membrane, } \\
\text { Cytoplasm }\end{array}$ \\
\hline $\begin{array}{l}\text { Sorbin and SH3 domain- } \\
\text { containing protein } 2\end{array}$ & $\begin{array}{l}\text { Adapter protein that plays a role in the assembling of signaling complexes, being a link between } \\
\text { ABL kinases and actin cytoskeleton. }\end{array}$ & Plasma membrane \\
\hline Sorbitol dehydrogenase & Converts sorbitol to fructose. & Mitochondrion \\
\hline Transgelin-2 [2x] & n.a. & Cytosol, Secreted \\
\hline $\begin{array}{l}\text { Tubulointerstitial nephritis } \\
\text { antigen }\end{array}$ & Mediates adhesion of proximal tubule epithelial cells via integrins alpha3-beta1 and alphaV-beta3. & Basement membrane \\
\hline Tropomyosin alpha-1 chain & Binds to actin filaments in muscle and non-muscle cells. & Cytoskeleton \\
\hline Pantetheinase & $\begin{array}{l}\text { Amidohydrolase that hydrolyzes specifically one of the carboamide linkages in D-pantetheine thus } \\
\text { recycling pantothenic acid (vitamin B5) and releasing cysteamine. }\end{array}$ & Plasma membrane \\
\hline
\end{tabular}

*, From Uniprot; n.a., not available. 

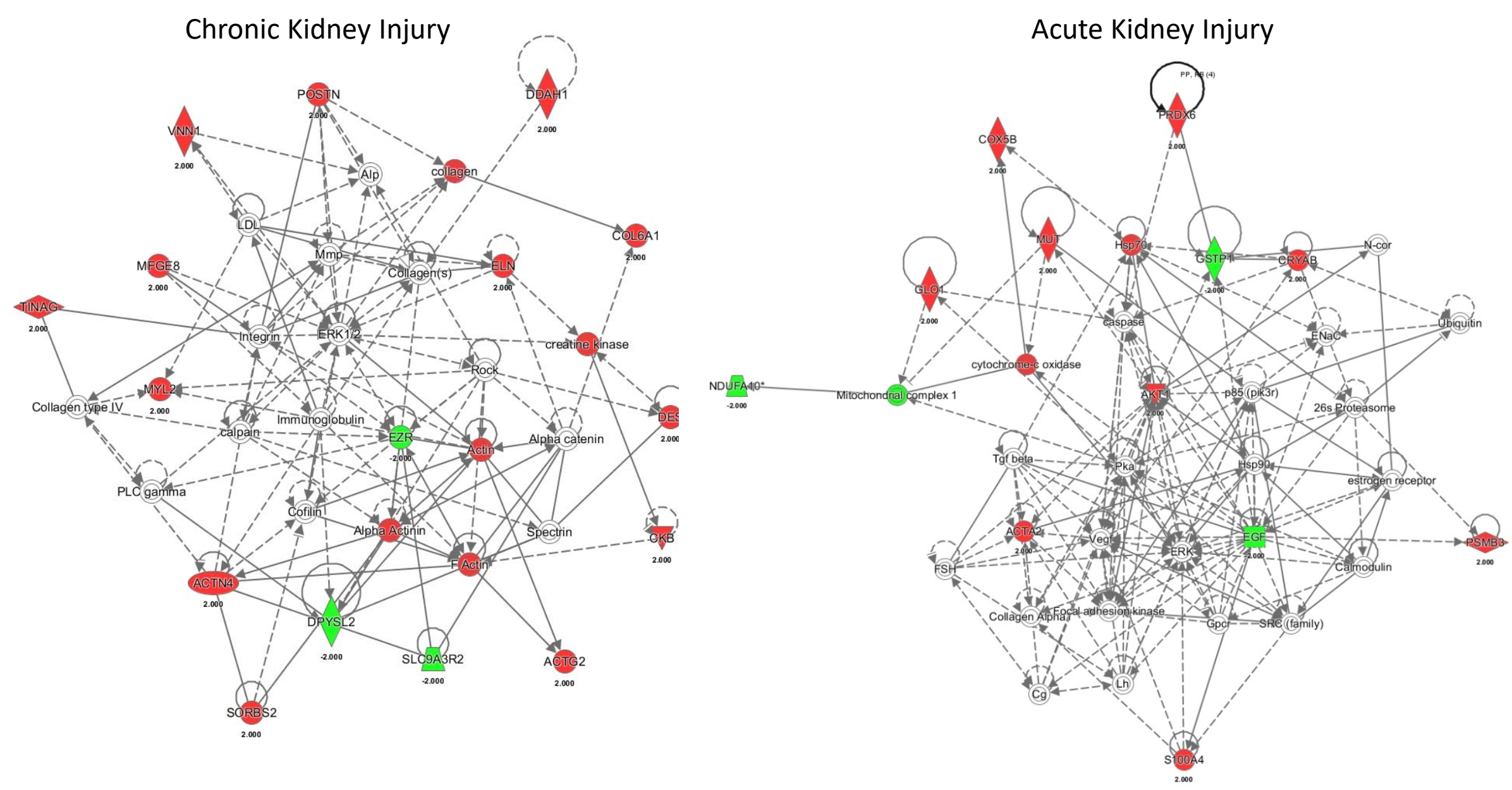

Figure 1 


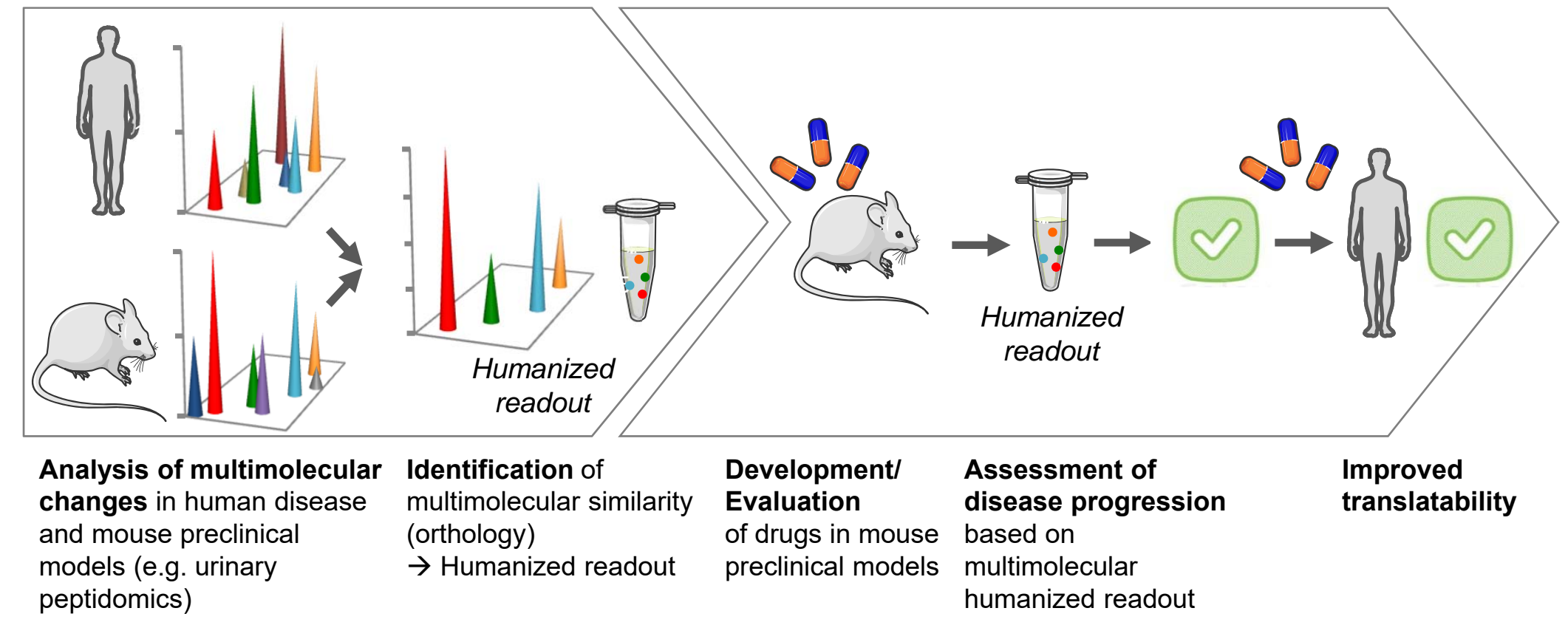

Figure 2 